doi: 10.18484/2305-0047.2020.2.173

A.O. NYKONENKO ${ }^{1,2}$, O.S. NYKONENKO ${ }^{1}$, D.A. BUGA ${ }^{2}$, I.V. RUSANOV ${ }^{2}$, S.R.VILDANOV ${ }^{1}$

\title{
HEALTH STATUS ASSESSMENT OF RELATED KIDNEY DONORS IN THE LATE POSTOPERATIVE PERIOD
}

\author{
Zaporizhzhya State Medical University ${ }^{1}$, \\ Zaporizhzhya Medical Academy of Postgraduate Education of the Ministry of Health of Ukraine ${ }^{2}$, Zaporizhia, \\ Ukraine
}

Цель. Изучить состояние здоровья живых доноров почки на основании степени восстановления функции почки и общего физического статуса донора.

Материал и методы. 37 родственных доноров почек перенесли нефрэктомию в период с 2014 по 2017

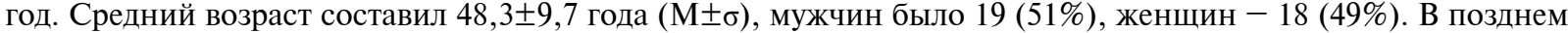
послеоперационном периоде $(1,9 \pm 1,1$ года $(\mathrm{M} \pm \sigma))$ изучали уровни протеинурии и скорости клубочковой фильтрации (СКФ). Качество жизни доноров почек оценивали с помощью опросника Medical Outcomes Study-Short Form-36.

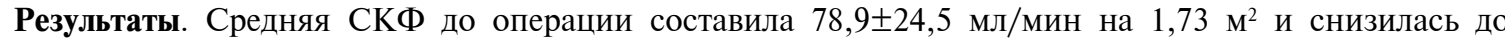
49,8 $\pm 11,2$ мл/мин на 1,73 м² на 2-е сутки после операции. При выписке $(15,2 \pm 7,0$ LYZ) средняя СКФ уве-

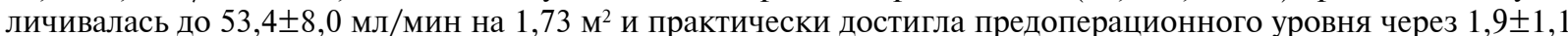
года. Отмечено повышение креатинина и увеличение протеинурии в ранние сроки с нормализацией этих показателей в отдаленные сроки. Это свидетельствует о том, что единственная почка с нормальной функцией способна компенсировать отсутствие контралатеральной. Кроме того, наше исследование показало, что в позднем послеоперационном периоде не было статистически значимой разницы ни по СКФ, ни по качеству жизни между донорами разных возрастных групп. Таким образом, при адекватной селекции пары донор-реципиент на основе комплексного обследования, трансплантация почки является не только эффективным методом лечения терминальной стадии хронической почечной недостаточности, но и безопасна для здоровья и дальнейшей почечной функции донора.

Заключение. У прижизненных доноров отмечается постепенное восстановление почечной функции, согласно СКФ, при выписке (день $15,2 \pm 7,0)$ и в позднем послеоперационном периоде $(1,9 \pm 1,1$ года) практически до предоперационного уровня. Физический и психологический компоненты здоровья доноров разных возрастных групп были сопоставимы.

Ключевые слова: трансплантаия, прижизненный донор почки, донорская нефрэктомия, послеоперационный период, почечная недостаточность

Objective. To analyze the health status of living kidney donors based on the degree of restoration of the kidney function and the general physical status of the donor.

Methods. 37 related kidney donors underwent nephrectomy between 2014 and 2017. The average age was 48.3 $\pm 9.7(\mathrm{M} \pm \sigma)$ years, with 19 men $(51 \%)$ and $18(49 \%)$ women. In the late postoperative period $(1,9 \pm 1,1$ years $(\mathrm{M} \pm \sigma))$, the levels of proteinuria, and glomerular filtration rate (GFR) were studied. The life quality of kidney donors was assessed using the Medical Outcomes Study-Short Form-36 questionnaire.

Results. The average GFR before the operation was $78,9 \pm 24,5 \mathrm{ml} / \mathrm{min}$ per $1.73 \mathrm{~m}^{2}$, and fell to $49,8 \pm 11,2$ $\mathrm{ml} / \mathrm{min}$ per $1.73 \mathrm{~m}^{2}$ on the $2^{\text {nd }}$ day after the operation. Upon discharge $(15,2 \pm 7,0$ day), average GFR increased to $53,4 \pm 8,0 \mathrm{ml} / \mathrm{min}$ per $1.73 \mathrm{~m}^{2}$, and almost reached pre-operation levels $1,9 \pm 1,1$ years after the operation. This suggests that a single normally-functioning kidney is capable of taking on the load from the missing kidney. Furthermore, our study showed that, in the late postoperative period, there was no statistically significant difference in either GFR or quality of life between the donors of different age groups $(p>0.05)$. Our research showed that if adequate protocols are used for living donor selection, donor-recipient kidney transplantation is not only an effective method for treating terminal stage of chronic end stage of renal disease, but is also safe for health and the subsequent renal function of the donor.

Conclusions. In living donors, a gradual restoration of renal function is observed, according to GFR, at

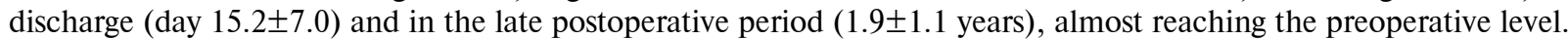
The physical and psychological health components of donors of different age groups were comparable.

Key words: transplantation, living kidney donor, donor nephrectomy, postoperative period, renal failure

Novosti Khirurgii. 2020 Mar-Apr; Vol 28 (2): 173-179

The articles published under CC BY NC-ND license Health Status Assessment of Related Kidney Donors in the Late Postoperative Period A.O. Nykonenko, O.S. Nykonenko, D.A. Buga, I.V. Rusanov, S.R.Vildanov 


\section{Научная новизна статьи}

Впервые изучены степень и сроки восстановления функции почек после донорской нефрэктомии. Проведен анализ качества жизни прижизненных доноров почки в позднем послеоперационном периоде. Установлено, что, при условии тщательного отбора доноров, почечная функция в позднем послеоперационном периоде была восстановлена практически до предоперационного уровня. При этом не было статистически значимой разницы между донорами различных возрастных групп по качеству жизни в позднем послеоперационном периоде.

\section{What this paper adds}

For the first time, the degree and timing of restoration of the renal function after donor nephrectomy has been studied. The analysis of the life quality of intravital kidney donors in the late postoperative period has been conducted. It has been found that, subject to careful selection of donors, the renal function in the late postoperative period is restored almost to the preoperative level. There was no statistically significant difference between donors of different age groups in terms of life quality in the late postoperative period.

\section{Introduction}

Today, kidney transplantation is the method of choice in the treatment of patients with endstage chronic renal failure. The guiding principle in transplantology should be the preservation of the health of living organ donors and the need for further observation so that the potential adverse effects of living organ donation could not negatively affect the health and life of the donor $[1,2]$. An integral indicator of the renal function of donors is the glomerular filtration rate (GFR) $[3,4,5,6,7]$

The International Organization for the Development of Recommendations "Improving the Global Outcomes for Kidney Diseases "(KDIGO), classifies GFR at three levels according to the safety indicators of a living kidney donor: $\geq 90 \mathrm{ml} / \min$ per $1,73 \mathrm{~m}^{2}$ as acceptable for kidney donation, $<60 \mathrm{ml} / \mathrm{min}$ per $1,73 \mathrm{~m}^{2}$ as unacceptable, and $60-90 \mathrm{ml} / \mathrm{min}$ per $1,73 \mathrm{~m}^{2}$ as an intermediate level, when the decision should be individualized based on the age and other clinical factors [8]. Literature data describing long-term observations and results in living kidney donors with GFR in the range of $60-90 \mathrm{ml} / \mathrm{min}$ per $1,73 \mathrm{~m}^{2}$ are limited [9].

In addition to GFR, another laboratory criterion that is commonly used to assess the renal function is the level of proteinuria $[5,7]$. In addition, in studies of the health indicators of living kidney donors, the use of life quality assessment is becoming increasingly popular $[1$, 6]. Numerous studies have used the Medical Outcomes Study-Short Form-36 questionnaire (MOS SF-36) to assess quality of life [1, 7]. It is worth noting that in assessing the life quality of living kidney donors, attention is not paid to the timing of restoring th kidney function, which requires further research.

Objective. To analyze the health status of living kidney donors based on the degree of restoration of the kidney function and the general physical status of the donor.

\section{Methods}

The data from 37 related kidney donors were retrospectively analyzed, who underwent donor nephrectomy from 2014 to 2017 in the hospital surgery clinic of Zaporizhzhya State Medical University (Ukraine). We studied the dynamics of levels of GFR, proteinuria and creatinine in living kidney donors before surgery, 2 days after surgery, at discharge $(15.2 \pm 7.0$ days $(\mathrm{M} \pm \sigma))$ and after $1.9 \pm 1.1$ years $(\mathrm{M} \pm \sigma)$. Donors visited the clinic for additional analysis of GFR and proteinuria. This time period was defined as a late postoperative period and corresponded to $1.9 \pm 1.1$ years $(\mathrm{M} \pm \sigma)$. GFR was calculated using the Cockcroft-Gault formula [3, 4]. The results of clinical and laboratory studies were interpreted according to the reference values of the biochemical laboratory of the Communal institution "Zaporizhzhya Regional Clinical Hospital".

The average age of donors at the time of surgery was $48.3 \pm 9.7$ years $(\mathrm{M} \pm \sigma)$. There were 19 men (51\%), 18 women (49\%). Donors were divided into 3 groups in accordance with the age classification of the World Health Organization (2015) [9]: young age (22-44 years $-8(21 \%)$, average age (44-60 years) $-24(65 \%)$, advanced age $(60-75$ years $)-5$ people (14\%).

In the laboratory study of kidney function in donors, all indicators were within the reference values, regardless of age.

The life quality of kidney donors was assessed using the MOS SF-36 questionnaire, consisting of 11 points, including 36 questions. The results were given in points (from 1 to 100) on 8 scales: physical functioning, the effect of the physical state on the role functioning, pain intensity, general health, life activity, social functioning, the influence of the emotional state on the role functioning, and self-esteem of mental health. The questionnaire allows formulating 2 basic generalized parameters: the physical and psychological components of health. 


\section{Statistics}

The database was compiled in the Excel program according to the primary documentation and the data of additional research methods in dynamics. All types of analysis were performed using the statistical analysis software packages Microsoft Office Excel 2003 and STATISTICA 6.0 for Windows (StatSoft.Inc., USA) v.6.1 license AXXR712D833214FAN5.

To describe the frequency data the percentage was used. All quantitative characteristics in the work were presented using the distribution parameters of the descriptive statistics.

To describe the selective normal distribution of quantitative traits, the mean value of the trait and the standard deviation $(\mathrm{M} \pm \sigma)$ were indicated. For a selective distribution of quantitative traits that differed from normal, the median (Me) was indicated, the lower and upper quartiles $-25 \%$ (LQ) and 75\% (UQ). The first step in the analysis of the quantitative data was to analyze the type of their distribution.

To obtain a reliable assessment of the correspondence of the studied phenomenon to the law of normal distribution, we tested the statistical hypothesis about the type of distribution, that is, whether the sample was selected from the general population in which the investigated trait has a normal distribution. According to the results of the analysis, one of the hypotheses was accepted:

- the null hypothesis that the distribution of the investigated trait in the general population corresponds to the law of normal distribution;

- the alternative hypothesis that the distribution of the investigated trait in the general population does not correspond to the law of normal distribution.

The critical level of statistical significance in the work is taken as 0.05 . If the obtained value of $\mathrm{p}$ for the statistical criterion was more than critical, then the null hypothesis was not rejected, that is, the distribution of the investigated trait was considered normal.

To check the form of data distribution, the Kolmogorov-Smirnov test was used.
To compare the average data of independent samples, the unpaired t-test was used. Nonparametric criteria were used to determine the significance of differences in quantitative characteristics, the distribution of which differed from normal, and also for small samples. At the same time, the Mann-Whitney U-test was used to compare two independent samples.

All qualitative features are presented in the form of contingency tables " $2 \times 2$ ". To compare qualitative characteristics, ordinal or nominal ones, the $\chi 2$ criterion and the Fisher exact test were used.

\section{Results}

Immediately after nephrectomy, the function of the only one kidney deteriorated. GFR decreased from $78.9 \pm 24.5 \mathrm{ml} / \mathrm{min}$ per $1.73 \mathrm{~m}^{2}$ to $49.8 \pm 11.2$ $\mathrm{ml} / \mathrm{min}$ per $1.73 \mathrm{~m}^{2}$, creatinine increased from 84.522 .6 to 145.524 .4 proteinuria up to 0.23 . At discharge (15.2 \pm 7.0 days), the average GFR increased to $53.4 \pm 8.0 \mathrm{ml} / \min$ per $1.73 \mathrm{~m}^{2}$, creatinine and proteinuria decreased. In the long term, all indicators were at the preoperative level (table 1, figure 1, 2).

The analysis of the indicators dynamics of the kidney function in different age groups in the long term after nephrectomy was carried out. There were no statistically significant differences in GFR, creatinine, proteinuria between age groups in the aforementioned time periods (table 2).

When analyzing the life quality of kidney donors in the long-term postoperative period (table 3 ), no statistically significant difference between different age groups was revealed ( $p>0.05)$.

\section{Discussion}

Some authors suggest that after nephrectomy, the risk of developing the renal failure in living donors increases $[10,11]$. Other authors point to a high relative and low absolute risk of the renal failure in renal allograft donors $[3,12,13]$. According to our analysis, renal function decreased on the $2^{\text {nd }}$ day after surgery, but improved upon discharge and gradually recovered to normal levels in the late postoperative

Laboratory results of donor renal function before and after nephrectomy

\begin{tabular}{lccccc}
\hline Indicators, measurement units & Norm & $\begin{array}{c}\text { Before } \\
\text { surgery }\end{array}$ & $\begin{array}{c}\text { 2 days after } \\
\text { surgery }\end{array}$ & $\begin{array}{c}\text { Discharge } \\
(15,2 \pm 7,0 \text { days })\end{array}$ & $\begin{array}{c}\text { Late post- } \\
\text { operative period } \\
(1,9 \pm 1,1 \text { years })\end{array}$ \\
\hline $\begin{array}{l}\text { Urine protein content, } \\
\text { g / 1 (Me, LQ, UQ) }\end{array}$ & Up to 0,033 & 0,00 & 0,23 & 0,06 & 0,01 \\
The level of creatinine in the & men: $61-115$ & $85,4 \pm 22,6$ & $145,5 \pm 24,4$ & $124,4 \pm 29,1$ & $93,8 \pm 19,7$ \\
blood serum, mol / 1 $(\mathrm{M} \pm \sigma)$ & women: $53-97$ & & & & $(0,001-0,03)$ \\
GFR, ml / solution / & $>90$ & $78,9 \pm 24,5$ & $49,8 \pm 11,2$ & $53,4 \pm 8,0$ & $74,9 \pm 22,5$ \\
$1.73 \mathrm{~m}^{2}(\mathrm{M} \pm \sigma)(\mathrm{M} \pm \sigma)$ & & & & & \\
\hline
\end{tabular}


period (table 1, Fig. 1, 2). This suggests that a single kidney with normal function is able to compensate for the absence of contralateral one. This is consistent with the literature data indicating the safety of kidney donation provided that donors are carefully selected $[5,6,7,14,15]$. It should be noted that the average preoperative GFR in our sample was $78.9 \pm 24.5 \mathrm{ml} /$ min per $1.73 \mathrm{~m} 2$, which corresponds to the intermediate level of KDIGO [8]. We have demonstrated that even in this group in the late postoperative period, GFR is restored almost to the preoperative level.

In addition, our study showed that there was no statistically significant difference in either GFR or quality of life between donors of different age groups ( $>0.05)$ in the late postoperative period (tables 2,
3). Some literature cites data on an increased risk of developing the renal failure in elderly donors [16]. Other authors refute this point of view and prove the acceptability of living organ donors of the advanced age [17]. According to our study, the development of the renal failure in elderly donors was not observed $1.9 \pm 1.1$ years after nephrectomy.

Thus, in case of adequate selection of the donor-recipient pair on the basis of a comprehensive examination, kidney transplantation is not only an effective treatment for the terminal stage of chronic renal failure, but also safe for the health and further renal function of the donor. However, further study of this issue is required with the inclusion of a larger number of respondents.

Fig 1. Cr levels and GFR in living kidney donors in the post-operative period.

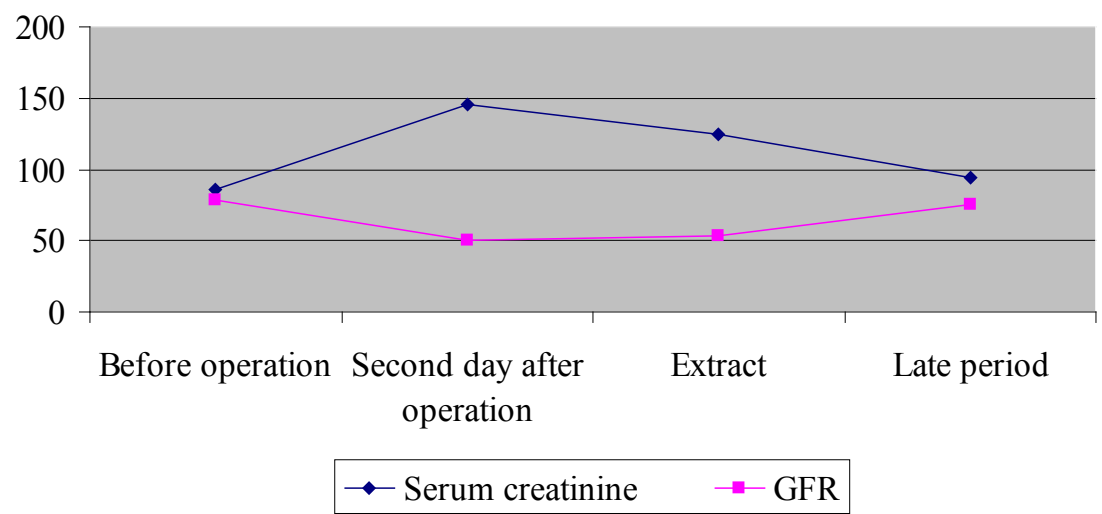

Fig 2. Levels of protein in the urine of living kidney donors.

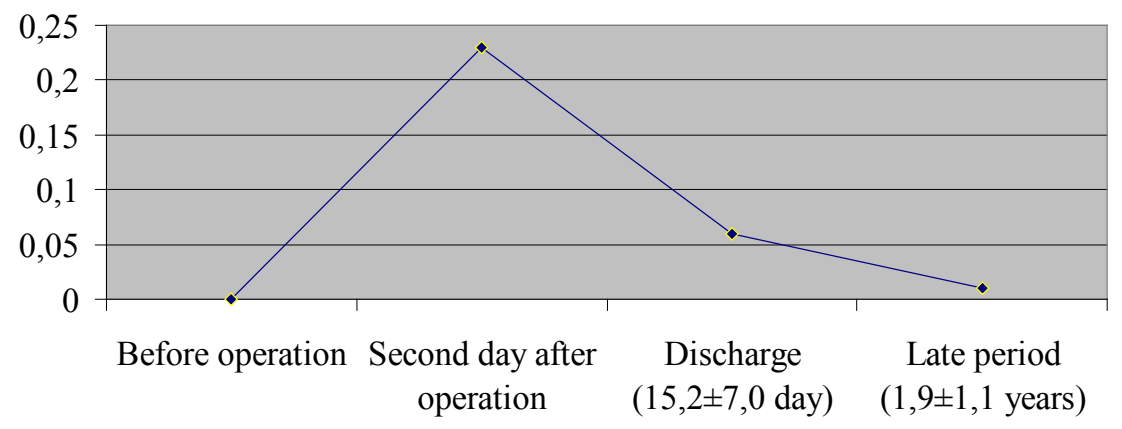

Protein content in the urine

Table 2

The results of laboratory studies of the renal function of donors of various age groups in the late terms $(1,9 \pm 1,1$ years) after nephrectomy

\begin{tabular}{lcccc}
\hline Indicators, measurement units & Norm & $\begin{array}{c}\text { Young age } \\
\text { donors }(\mathrm{n}=8)\end{array}$ & $\begin{array}{c}\text { Middle age } \\
\text { donors }(\mathrm{n}=24)\end{array}$ & $\begin{array}{c}\text { Advanced age } \\
\text { donors }(\mathrm{n}=5)\end{array}$ \\
\hline $\begin{array}{l}\text { Urine protein content, } \\
\mathrm{g} / 1(\mathrm{Me}, \mathrm{LQ}, \mathrm{UQ})\end{array}$ & $\mathrm{Up}$ to 0,033 & $0,00(0,00-0,02)$ & $0,00(0,00-0,01)$ & $0,00(0,00-0,02)$ \\
$\begin{array}{l}\text { The level of creatinine in the blood } \\
\text { serum, mol / }(\mathrm{M} \pm \sigma)\end{array}$ & $\begin{array}{c}\text { men: } 61-115 \\
\text { women: } 53-97\end{array}$ & $93,5 \pm 20,9$ & $91,7 \pm 21,6$ & $92,3 \pm 20,3$ \\
$\begin{array}{l}\text { GFR, ml / solution / } \\
1.73 \mathrm{~m}^{2}(\mathrm{M} \pm \sigma)(\mathrm{M} \pm \sigma)\end{array}$ & $>90$ & $77,6 \pm 22,2$ & $77,8 \pm 23,7$ & $74,8 \pm 23,9$ \\
\hline
\end{tabular}


Analysis of the life quality of kidney donors (questionnaire MOS SF-36) in the long-term postoperative period $(\mathrm{M} \pm \sigma)$

\begin{tabular}{|c|c|c|c|c|}
\hline № & Grading scales & $\begin{array}{l}\text { Young age donors } \\
(n=8)\end{array}$ & $\begin{array}{l}\text { Middle age donors } \\
\quad(\mathrm{n}=24)\end{array}$ & $\begin{array}{l}\text { Advanced age donors } \\
(\mathrm{n}=5)\end{array}$ \\
\hline 1. & Physical functioning & $87,2 \pm 14,8$ & $86,3 \pm 15,5$ & $83,9 \pm 16,2$ \\
\hline 2. & $\begin{array}{l}\text { The influence of physical condition on the } \\
\text { role functioning }\end{array}$ & $94,4 \pm 11,0$ & $93,8 \pm 11,6$ & $91,7 \pm 12,5$ \\
\hline 3. & Pain intensity & $80,9 \pm 24,2$ & $85,9 \pm 20,4$ & $84,6 \pm 19,5$ \\
\hline 4. & General health & $70,1 \pm 24,8$ & $71,1 \pm 26,3$ & $69,0 \pm 25,4$ \\
\hline 5. & Life activity & $71,7 \pm 23,3$ & $74,4 \pm 23,4$ & $73,9 \pm 21,9$ \\
\hline 6. & Social functioning & $94,4 \pm 9,1$ & $95,3 \pm 9,3$ & $93,1 \pm 11,0$ \\
\hline 7. & $\begin{array}{l}\text { The influence of emotional state on the role } \\
\text { functioning }\end{array}$ & $92,6 \pm 22,2$ & $91,7 \pm 23,6$ & $92,6 \pm 22,2$ \\
\hline 8. & Self-assessment of mental health & $79,1 \pm 16,2$ & $82,0 \pm 14,7$ & $80,0 \pm 14,9$ \\
\hline 9.1 & The physical component of health & $51,3 \pm 6,7$ & $51,5 \pm 7,1$ & $50,6 \pm 7,2$ \\
\hline 9.2 & The psychological component of health & $54,2 \pm 7,9$ & $55,2 \pm 7,9$ & $54,8 \pm 7,5$ \\
\hline
\end{tabular}

\section{Conclusions}

In living donors, a gradual restoration of renal function is observed, according to GFR, at discharge (day 15.2 \pm 7.0 ) and in the late postoperative period (1.9 \pm 1.1 years), almost reaching the preoperative level. The physical and psychological components of the health of donors of different age groups were comparable.

\section{Funding}

The work was carried out in accordance with the plan of scientific works of Zaporizhzhya State Medical University.

\section{Conflict of interest}

The authors declare that they have no conflict of interest.

\section{Ethical aspects. Ethics Committee approval}

The work was approved by the Committee on the Ethics of Zaporizhzhya State Medical University.

\section{ЛИТЕРАТУРА}

1. Готье СВ, Константинов ВК. Методы оценки качества жизни прижизненныхдоноров органов. Вестн Трансплантологии и Искусств Органов. 2017;19(1):8288. doi: 10.15825/1995-1191-2017-1-82-88

2. Lentine KL, Kasiske BL, Levey AS, Adams PL, Alberú J, Bakr MA, Gallon L, Garvey CA, Guleria S, Li PK, Segev DL, Taler SJ, Tanabe K, Wright L, Zeier MG, Cheung M, Garg AX. KDIGO clinical practice guideline on the evaluation and care of living kidney donors. Transplantation. 2017 Aug;101(8S Suppl 1):S1-S109. doi: 10.1097/TP.0000000000001769
3. Levey AS, Inker LA. GFR evaluation in living kidney donor candidates. J Am Soc Nephrol. 2017 Apr;28(4):1062-71. Published online 2017 Mar 15. doi: 10.1681/ASN.2016070790

4. Inker LA, Koraishy FM, Goyal N, Lentine KL. Assessment of glomerular filtration rate and end-stage kidney disease risk in living kidney donor candidates: a paradigm for evaluation, selection, and counseling. Adv Chronic Kidney Dis. 2018 Jan;25(1):21-30. doi: https://doi.org/10.1053/j.ackd.2017.09.002

5. Mehta KS, Swami R, Pajai A, Bhurke S, Shirkande A, Jawle S. Long-term evaluation of kidney function in live-related kidney donors. Saudi J Kidney Dis Transpl. 2017 Sep-Oct;28(5):1041-49. doi: 10.4103/13192442.215145

6. Janki S, Dols LFC, Timman R, Mulder EEAP, Dooper IMM, van de Wetering J, IJzermans JNM. Five-year follow-up after live donor nephrectomy cross-sectional and longitudinal analysis of a prospective cohort within the era of extended donor eligibility criteria. Transpl Int. 2017 Mar;30(3):266-76. https:// doi.org/10.1111/tri.12872

7. Han X, Lim JY, Raman L, Tai BC, Kaur H, Goh AT, Vathsala A, Tiong HY. Nephrectomy-induced reduced renal function and the health-related quality of life of living kidney donors. Clin Transplant. 2017 Mar;31(3). doi: 10.1111/ctr.12910

8. Levey AS, Inker LA. GFR Evaluation in Living Kidney Donor Candidates. J Am Soc Nephrol. 2017 Apr;28(4):1062-71. doi: 10.1681/ASN.2016070790

9. Kasiske BL, Asrani SK, Dew MA, Henderson ML, Henrich C, Humar A, Israni AK, Lentine KL, Matas AJ, Newell KA, LaPointe Rudow D, Massie AB, Snyder JJ, Taler SJ, Trotter JF, Waterman AD. The living donor collective: a scientific registry for living donors. Am J Transplant. 2017 Dec;17(12):3040-48. doi: 10.1111/ajt.14365

10. Mjøen G, Holdaas H. Long term risk of mortality after living kidney donation. BMJ. 2017 Apr 25;357:j1770. doi: 10.1136/bmj.j1770

11. Boudville N, Garg AX. End-stage renal disease in living kidney donors. Kidney Int. 2014 Jul;86(1):20-22. doi: 10.1038/ki.2013.560

12. O'Keeffe LM, Ramond A, Oliver-Williams C, Willeit P, Paige E, Trotter P, Evans J, Wadström J, Nicholson M, Collett D, Di Angelantonio E. Mid- 
and long-term health risks in living kidney donors: a systematic review and meta-analysis. Ann Intern Med. 2018 Feb 20;168(4):276-84. doi: 10.7326/M17-1235 13. Muzaale AD, Massie AB, Wang MC, Montgomery RA, McBride MA, Wainright JL, Segev DL. Risk of end-stage renal disease following live kidney donation. JAMA. 2014 Feb 12;311(6):579-86. doi: 10.1001/ jama.2013.285141

14. Matas AJ, Vock DM, Ibrahim HN. GFR $\leq 25$ years postdonation in living kidney donors with (vs. without) a first-degree relative with ESRD. Am J Transplant. 2018 Mar;18(3):625-31. doi: 10.1111/ajt.14525

15. Yalin SF, Trabulus S, Seyahi N, Cengiz M, Cicik ME, Altiparmak MR. Ambulatory blood pressure monitoring in living kidney donors: What changes in 10 years? Clin Transplant. 2018 Apr;32(4):e13224. doi: $10.1111 /$ ctr. 13224

16. Wainright JL, Robinson AM, Wilk AR, Klassen DK, Cherikh WS, Stewart DE. Risk of ESRD in prior living kidney donors. Am J Transplant. 2018 May;18(5):1129-39. doi: 10.1111/ajt.14678

17. Lam NN, Garg AX. Acceptability of older adults as living kidney donors. Curr Opin Nephrol Hypertens. 2016 May;25(3):245-56. doi: 10.1097/ MNH.0000000000000215

\section{REFERENCES}

1. Gautier SV, Konstantinov VK. Assessment Methods of Quality of Life of Living Organ Donors. Russian Journal of Transplantology and Artificial Organs. 2017;19(1):82-88. https://doi.org/10.15825/1995-11912017-1-82-88 (In Russ.)

2. Lentine KL, Kasiske BL, Levey AS, Adams PL, Alberú J, Bakr MA, Gallon L, Garvey CA, Guleria S, Li PK, Segev DL, Taler SJ, Tanabe K, Wright L, Zeier MG, Cheung M, Garg AX. KDIGO clinical practice guideline on the evaluation and care of living kidney donors. Transplantation. 2017 Aug;101(8S Suppl 1):S1-S109. doi: 10.1097/TP.0000000000001769

3. Levey AS, Inker LA. GFR evaluation in living kidney donor candidates. J Am Soc Nephrol. 2017 Apr;28(4):1062-71. Published online 2017 Mar 15. doi: 10.1681/ASN.2016070790

4. Inker LA, Koraishy FM, Goyal N, Lentine KL. Assessment of glomerular filtration rate and end-stage kidney disease risk in living kidney donor candidates: a paradigm for evaluation, selection, and counseling. Adv Chronic Kidney Dis. 2018 Jan;25(1):21-30. doi: https://doi.org/10.1053/j.ackd.2017.09.002

5. Mehta KS, Swami R, Pajai A, Bhurke S, Shirkande A, Jawle S. Long-term evaluation of kidney function in liverelated kidney donors. Saudi J Kidney Dis Transpl. 2017 Sep-Oct;28(5):1041-49. doi: 10.4103/1319-2442.215145

6. Janki S, Dols LFC, Timman R, Mulder EEAP,

\section{Адрес для корреспонденции}

69035, Украина, г. Запорожье, проспект Маяковского, д. 26, Запорожский государственный медицинский университет, кафедра госпитальной хирургии, тел.: +38 (097)-594-54-93, e-mail: nikonandra@gmail.com, Никоненко Андрей Александрович
Dooper IMM, van de Wetering J, IJzermans JNM. Five-year follow-up after live donor nephrectomy cross-sectional and longitudinal analysis of a prospective cohort within the era of extended donor eligibility criteria. Transpl Int. 2017 Mar;30(3):266-76. https:// doi.org/10.1111/tri.12872

7. Han X, Lim JY, Raman L, Tai BC, Kaur H, Goh AT, Vathsala A, Tiong HY. Nephrectomy-induced reduced renal function and the health-related quality of life of living kidney donors. Clin Transplant. 2017 Mar;31(3). doi: 10.1111/ctr.12910

8. Levey AS, Inker LA. GFR Evaluation in Living Kidney Donor Candidates. J Am Soc Nephrol. 2017 Apr;28(4):1062-71. doi: 10.1681/ASN.2016070790

9. Kasiske BL, Asrani SK, Dew MA, Henderson ML, Henrich C, Humar A, Israni AK, Lentine KL, Matas AJ, Newell KA, LaPointe Rudow D, Massie AB, Snyder JJ, Taler SJ, Trotter JF, Waterman AD. The living donor collective: a scientific registry for living donors. Am J Transplant. 2017 Dec;17(12):3040-48. doi: 10.1111 /ajt.14365

10. Mjøen G, Holdaas H. Long term risk of mortality after living kidney donation. BMJ. 2017 Apr 25;357:j1770. doi: 10.1136/bmj.j1770

11. Boudville N, Garg AX. End-stage renal disease in living kidney donors. Kidney Int. 2014 Jul;86(1):20-22. doi: $10.1038 / \mathrm{ki} .2013 .560$

12. O'Keeffe LM, Ramond A, Oliver-Williams C, Willeit P, Paige E, Trotter P, Evans J, Wadström J, Nicholson M, Collett D, Di Angelantonio E. Midand long-term health risks in living kidney donors: a systematic review and meta-analysis. Ann Intern Med. 2018 Feb 20;168(4):276-84. doi: 10.7326/M17-1235

13. Muzaale AD, Massie AB, Wang MC, Montgomery RA, McBride MA, Wainright JL, Segev DL. Risk of end-stage renal disease following live kidney donation. JAMA. 2014 Feb 12;311(6):579-86. doi: 10.1001/ jama.2013.285141

14. Matas AJ, Vock DM, Ibrahim HN. GFR $\leq 25$ years postdonation in living kidney donors with (vs. without) a first-degree relative with ESRD. Am J Transplant. 2018 Mar;18(3):625-31. doi: 10.1111/ajt.14525

15. Yalin SF, Trabulus S, Seyahi N, Cengiz M, Cicik ME, Altiparmak MR. Ambulatory blood pressure monitoring in living kidney donors: What changes in 10 years? Clin Transplant. 2018 Apr;32(4):e13224. doi: 10.1111/ctr.13224

16. Wainright JL, Robinson AM, Wilk AR, Klassen DK, Cherikh WS, Stewart DE. Risk of ESRD in prior living kidney donors. Am J Transplant. 2018 May;18(5):1129-39. doi: 10.1111/ajt.14678

17. Lam NN, Garg AX. Acceptability of older adults as living kidney donors. Curr Opin Nephrol Hypertens. 2016 May;25(3):245-56. doi: 10.1097/ MNH.0000000000000215

\section{Address for correspondence}

69035, Ukraine, Zaporizhia, pr. Maiakovskii 26,

Zaporizhzhya State Medical University, the Hospital Surgery Chair, tel. +38 (097)-594-54-93, e-mail: nikonandra@gmail.com, Nykonenko Andriy A. 
Сведения об авторах

Никоненко Андрей Александрович, д.м.н., професcop, заведующий кафедрой госпитальной хирургии, Запорожский государственный медицинский университет, г. Запорожье, Украина.

https://orcid.org/0000-0002-5720-2602

Никоненко Александр Семенович, д.м.н., профессор, академик НАМН Украины, член-корреспондент НАН Украины, ректор, Запорожская медицинская академия последипломного образования Министерства здравоохранения Украины, г. Запорожье, Украина.

https://orcid.org/0000-0001-7333-4165

Буга Дмитрий Андреевич, к.м.н., доцент, заведующий кафедрой трансплантологии и эндокринной хирургии с курсом сердечно-сосудистой хирургии, Запорожская медицинская академия последипломного образования Министерства здравоохранения Украины, г. Запорожье, Украина.

https://orcid.org/0000-0001-5818-3100

Русанов Игорь Владимирович, к.м.н., доцент кафедры трансплантологии и эндокринной хирургии с курсом сердечно-сосудистой хирургии, Запорожская медицинская академия последипломного образования Министерства здравоохранения Украины, г. Запорожье, Украина.

https://orcid.org/0000-0002-4363-1158

Вильданов Сергей Ренатович, к.м.н, ассистент кафедры госпитальной хирургии, Запорожский государственный медицинский университет, г. Запорожье, Украина.

https://orcid.org/0000-0003-3885-9390

\section{Информация о статье}

Поступила 2 сентября 2019 г.

Принята в печать 20 апреля 2020 г.

Доступна на сайте 15 мая 2020 2.
Information about the authors

Nykonenko Andriy O., Doctor of Medical Sciences (MD), Professor, Head of the Hospital Surgery Chair, Zaporizhzhya State Medical University, Zaporizhia, Ukraine.

https://orcid.org/0000-0002-5720-2602

Nykonenko Olexandr S., Doctor of Medical Sciences (MD), Professor, Academician of NAMS of Ukraine, Corresponding Member of NAS of Ukraine, Rector, Zaporizhzhya Medical Academy of Postgraduate Education of the Ministry of Health of Ukraine , Zaporizhia, Ukraine. https://orcid.org/0000-0001-7333-4165

Buga Dmitrii A., Doctor of Medical Sciences, (MD), Associate Professor, Head of the Chair of Transplantology and Endocrine Surgery with the Courses of the Cardiovascular Surgery, Zaporizhzhya Medical Academy of Postgraduate Education of the Ministry of Health of Ukraine, Zaporizhia, Ukraine. https://orcid.org/0000-0001-5818-3100

Rusanov Ihor V., Candidate of Medical Sciences (PhD), Associate Professor of the Chair of Transplantology and Endocrine Surgery with the Courses of the Cardiovascular Surgery, Zaporizhzhya Medical Academy of Postgraduate Education of the Ministry of Health of Ukraine, Zaporizhia, Ukraine.

https://orcid.org/0000-0002-4363-1158

Vildanov Serhii R., Candidate of Medical Sciences (PhD), Assistant of the Hospital Surgery Chair, Zaporizhzhya State Medical University, Zaporizhia, Ukraine.

https://orcid.org/0000-0003-3885-9390

\section{Article history}

Arrived: 02 September 2019

Accepted for publication: 20 April 2020

Available online: 15 May 2020 